\title{
Dyspepsia in coalminers and the general population: comparative study
}

\author{
J D HARRISON, D L MORRIS \\ From the Department of Surgery, Queen's Medical Centre, Nottingham NG7 2UH, UK
}

Coalminers have an increased incidence of gastric cancer ${ }^{12}$ with an overall excess mortality of $30-50 \%$, rising as high as fivefold in parts of south Wales. ${ }^{3}$ If screening for gastric cancer is to be cost effective in the West high risk groups will probably need to be identified and if dyspepsia is to be used to identify a particularly high risk group, such as coalminers, then we must know the rate of dyspepsia in the group we are studying and the extent to which it differs from the general population. We have therefore studied a group of coalminers and an age and sex matched group of subjects from the general population to see if the rates of dyspepsia differ between the two groups with a view to screening this high risk group for gastric cancer.

\section{Patients and methods}

A group of 670 coalminers aged 50-75 was identified from the records of the North Nottinghamshire Miners' Pension Fund and a group of 743 age and sex matched non-coalmining subjects was identified from general practitioner records in three participating practices. A self administered questionnaire on upper gastrointestinal symptoms was sent to the subjects in each group with a reply paid envelope. A reminder letter and questionnaire was sent six weeks later to subjects who had not replied.

The signatory of the letter to the miners was the president of the Union of Democratic Mineworkers and for the controls the patient's general practitioner. The letter and questionnaire were kept as simple as possible. The questionnaire included six questions about upper gastrointestinal symptoms: loss of appetite, loss of more than $6 \mathrm{~kg}$ in weight, difficulty in swallowing, epigastric pain, heartburn, and vomiting. Also included were inquiries about previous gastric surgery and use of tobacco (including tobacco chewing in the questionnaire to the miners). The relative proportions of each of the responses were compared using the $\chi^{2}$ test.

Accepted 18 July 1988

\section{Results}

Altogether $569(76.6 \%)$ of the general population anథ $516(77 \%)$ of the miners replied. There was nos significant difference in response rate to the question naire according to age, taking five year intervals from $50-75$ in each group $\left(\chi^{2}=7 \cdot 30, D F=9, N S\right)$. Of those who replied, 195 miners were positive for at least one symptom and 172 were positive in the general popula tion group $\left(\chi^{2}=5.88, p<0.05\right)$.

Comparing each of the symptoms (table 1), sig nificantly more miners complained of anorexia and weight loss, whereas similar numbers in both groupso complained of dysphagia, epigastric pain, heartburn; and vomiting. Significantly more miners had hao gastric surgery for benign disease and significantlys more miners smoked than the general population. As ao corollary of this, there were significantly more ex。्ञ smokers in the general population group. Few miner\& continue to chew tobacco after they retire $(14-2 \cdot 7 \%) \overrightarrow{\overrightarrow{0}}$ but this habit was common when they worked when $139(27 \%)$ miners took tobacco in this form either solely or in conjunction with smoking (table 2).

\section{Discussion}

Most published data (including those of the Registra General for England and Wales) support the cono clusion that coalminers have an average excess moro tality for gastric cancer of approximately $50 \%$, rising to fivefold in some regions ${ }^{1-6}$; some studies have failed to show this excess. ${ }^{78}$ There have been several hypo $\frac{7}{2}$

Table 1 Symptomanalysis

\begin{tabular}{|c|c|c|c|c|}
\hline Symptom & $\begin{array}{l}\text { General } \\
\text { population } \\
(n=569)\end{array}$ & $\begin{array}{l}\text { Miners } \\
(n=516)\end{array}$ & $\chi^{2}$ & $p$ \\
\hline $\begin{array}{l}\text { Anorexia } \\
\text { Weight loss } \\
\text { Dysphagia } \\
\text { Epigastric pain } \\
\text { Heartburn } \\
\text { Vomiting }\end{array}$ & $\begin{array}{r}14 \\
8 \\
15 \\
84 \\
135 \\
25\end{array}$ & $\begin{array}{r}43 \\
37 \\
25 \\
88 \\
138 \\
33\end{array}$ & $\begin{array}{r}17 \cdot 54 \\
21 \cdot 15 \\
2.98 \\
0 \cdot 77 \\
0 \cdot 35 \\
3 \cdot 45\end{array}$ & $\begin{array}{l}<0.00 k \\
<0.000 \\
\text { NS } \\
\text { NS } \\
\text { NS } \\
\text { NS }\end{array}$ \\
\hline Previous gastric surgery & 25 & 46 & 8.47 & $<0.01 \frac{1}{(1)}$ \\
\hline
\end{tabular}


Table 2 Tobacco habits

\begin{tabular}{lllll}
\hline & $\begin{array}{l}\text { General } \\
\text { population } \\
(n=569)\end{array}$ & $\begin{array}{l}\text { Miners } \\
(n=516)\end{array}$ & $\chi^{2}$ & $p$ \\
\hline Symptom & 160 & 201 & 14.90 & $<0.01$ \\
Current smokers & 285 & 215 & 6.49 & $<0.05$ \\
Ex-smokers & $14(2.7 \%)$ & - & - \\
Tobacco chewers & - & $139(27 \%)$ & - & - \\
\hline
\end{tabular}

theses to account for an excess mortality, including an effect of socioeconomic status, ${ }^{2}$ since miners were of social class $\mathbf{V}$ earlier this century and this class has a $50 \%$ excess for gastric cancer compared with the higher social classes.' Other hypotheses relate to the potentially carcinogenic effects of coal dust alone ${ }^{9}$ or after conversion of aromatic coal derivatives to mutagenic nitroso compounds in the stomach. ${ }^{1011}$

Another study has shown a positive association between gastric cancer and exposure to coal dust in those miners who smoked. ${ }^{12}$ Polynuclear aromatic compounds have been shown to be effective as carcinogens, especially when in particulate form, ${ }^{13}$ whereas statistical associations have been noted in men between atmospheric pollution and coalmining. ${ }^{14}$ Significantly more miners complain of anorexia and weight loss than the general population, which may be related to the destabilisation of the gastric mucosa engendered by a lifetime of exposure to the environmental conditions in coalmines, although clearly these symptoms could also be related to the asthenia of chronic respiratory disease that is so common in coalminers. Also relevant in the context of increased risk of gastric cancer is the finding that significantly more miners have had surgery for benign peptic ulcer disease, with an associated increase in the risk of developing a stump carcinoma. Another possible factor resulting in an increased risk of gastric cancer is the more common use of tobacco by coalminers. The carcinogenic effects of smoking on the respiratory tract are well known but the effect of smoking on the stomach is less well known, although there is much circumstantial evidence that smokers are at a higher risk of developing gastric carcinoma. There have also been studies to suggest that unburned tobacco in the form of snuff or chewing tobacco has a carcinogenic effect on gastric mucosa and it is of note that $27 \%$ of coalminers in our survey have chewed tobacco.

Other studies have shown that smoking is an aetiological factor for gastric cancer either by itself or more potently when combined with another factor such as exposure to coal dust or the consumption of alcohol.
Although the response rate to our questionnaire was relatively low, there was no evidence that the responding group differed from the non-responders, so it seems unlikely that bias could be introduced as a result of any disparity between the groups. We have found that coalminers complain more frequently of anorexia and weight loss, have a higher prevalence of previous gastric surgery, and have a higher proportion of smokers than an age and sex matched group of the general population. These findings could help to explain the higher incidence of gastric cancer among coalminers and we would suggest that they would be a suitable group to screen for gastric carcinoma using an upper gastrointestinal symptom questionnaire.

We are grateful to the Cancer Research Campaign for funding this research and to the management of the Union of Democratic Mineworkers, the North Nottinghamshire Miners' Pension Fund, and the Nottinghamshire general practitioners for participating in the study.

\section{References}

1 Registrar General, Occupational mortality statistics 1920-1980. London: HMSO, 1921-81.

2 Stocks P. On the death rates from cancer of the stomach and respiratory diseases in 1949-53 among coal miners and other male residents in counties of England and Wales. Br J Cancer 1961:16:592-8.

3 Craven JL, Baum M, West RR. Variations in gastric cancer mortality in south Wales. Clin Oncol 1979;5:341-51.

4 Rockette HE. Cause specific mortality of coal miners. J Occup Med 1977;19:795-801.

5 Atuhaire LK, Campbell MJ, Cochrane AL, Jones M, Moore F. Gastric cancer in a south Wales valley. Br J Ind Med 1986;43:350-2.

6 Davies JM. Stomach cancer mortality in Worksop and other Nottinghamshire mining towns. Br J Cancer 1980;41:438-45.

7 Swaen GM, Aerdts CW, Slangen JJ. Gastric cancer in coalminers: final report. Br J Ind Med 1987;44:777-9.

8 Weinberg GB, Kuller LH, Stehr PA. A case-control study of stomach cancer in a coal mining region of Pennsylvania. Cancer 1985;56:703-13.

9 Ames RG, Gamble JF. Lung cancer, stomach cancer, and smoking status among coal miners. A preliminary test of a hypothesis. Scand J Work Environ Health 1983;9:443-8.

10 Ong TM, Whong WZ, Ames RG. Gastric cancer in coal miners: an hypothesis of coal mine dust causation. Med Hypotheses 1983;12:159-65.

11 Whong WZ, Long R, Ames RG, Ong TM. Role of nitrosation in the mutagenic activity of coal dust: a postulation for gastric carcinogenesis in coal miners. Environ Res 1983;32:298-304.

12 Ames RG. Gastric cancer and coal mine dust exposure. A casecontrol study. Cancer 1983;52:1346-50.

13 Falk HL, Jurgelski W Jr. Health effects of coal mining and combustion: carcinogens and cofactors. Environ Health Perspect 1979;33:203-26.

14 Ashley DJ. Environmental factors in the aetiology of gastric cancer. Br J Prev Soc Med 1969;23:187-9. 